\title{
Rheological behavior of corn and soy mix as feed ingredients
}

\author{
Comportamento reológico de mistura de milho e soja para produção de rações
}

\author{
Marcos FRAIHA $^{1 *}$, João Domingos BIAGI ${ }^{1}$, Antonio Carlos de Oliveira FERRAZ ${ }^{1}$
}

\begin{abstract}
Foods behave as non-Newtonian fluids, but little is known about how corn and soybean mix behave under viscometric flow. In order to characterize the rheological behavior of animal feed under viscometric flow, a 70:30 (mass:mass) mixture of ground corn and soybean grains was submitted to a capillary rheometer at 3 different temperatures $\left(80,120\right.$, and $\left.160{ }^{\circ} \mathrm{C}\right)$, different moisture levels $(26.5 \pm 0.08 ; 30.4 \pm 0.31$, and $33.4 \pm 0.05 \%)$, and 4 shear rates $(30.4 ; 72.9 ; 304.3$, and $728.6 /$ second). Different strain rates and die dimensions were used to obtain the target shear rates. The resulting data were fitted to Power Law, Casson, and Bingham models. Based on experimental data, water content, mass temperature, and the effects of shear rate on the apparent shear viscosity of corn-soy mix were fitted to a single expression ( $\mathrm{p}<0.001$, $\left.\mathrm{R}^{2}=0.93\right): \eta=18,769.7(\dot{\gamma})^{-0.86} \mathrm{e}^{(-9.34 \mathrm{U}+935 \mathrm{~T})}$, where $\dot{\gamma}$ is shear rate, $\mathrm{U}$ is sample moisture, and $\mathrm{T}$ is sample temperature in Kelvin scale. As expected, such mixture presented a pseudoplastic (shear-thinning) behavior.

Keywords: viscometric flow; shear; shear-thinning; capillary rheometer.
\end{abstract}

\section{Resumo}

Alimentos comportam-se como fluidos não newtonianos, porém pouco se sabe do comportamento de milho e soja sob escoamento viscométrico. Para caracterizar o comportamento reológico de alimentos para animais, uma mistura de grãos de milho e soja moídos na proporção 70:30 (massa:massa) foi submetida ao reômetro capilar sob 3 níveis de temperatura $\left(80,120\right.$ e $\left.160{ }^{\circ} \mathrm{C}\right)$, umidade da massa $(26,5$ $\pm 0,08 ; 30,4 \pm 0,31$; e 33,4 \pm 0,05\%), e 4 taxas de cisalhamento aparente $(30,4 ; 72,9 ; 304,3$; e 728,6/second). Diferentes taxas de deformação e dimensões da matriz foram utilizadas para obtenção das taxas de cisalhamento acima. Os dados obtidos foram ajustados para os modelos da Lei da Potência, Casson e Bingham. Baseados nos dados experimentais, os efeitos de umidade, temperatura da massa e taxa de cisalhamento sobre a mistura de milho e soja foram ajustados para uma expressão única $\left(\mathrm{p}<0,001, \mathrm{R}^{2}=0,93\right): \eta=18.769,7(\dot{\gamma})^{-0,86} \mathrm{e}^{(-9,34 \mathrm{U}+935 \mathrm{~T})}$, onde $\dot{\gamma}$ é a taxa de cisalhamento, U é a de teor de água na amostra e T é a temperatura na massa, em escala Kelvin. Como esperado, a mistura de milho e soja moídos apresentou comportamento pseudoplástico.

Palavras-chave: escoamento viscométrico; cisalhamento; pseudoplástico; reômetro capilar.

\section{Introduction}

The current technological status of animal feed production justifies the use of ingredient and feed processing procedures, such as expansion, extrusion, and pelleting.

The mechanical behavior of those ingredients and their interaction with processing machinery are reflected in operating parameters such as: energy demand, operating capacity, and equipment use, as well as in the final properties of products, such as level of expansion and cooking, coloring, density, and texture.

It is known that extruded foods behave as non-Newtonian fluids, and their viscosity can be described by the Power Law model (CARVALHO; ASCHERI; MITCHELL, 2004; LI; CAMPANELLA; HARDACRE, 2004; SINGH; SMITH, 1999; EERIKAINEN; LINKO, 1998; RAO; ANANTHESWARAN 1982; REMSEN; CLARK, 1978). However, little is known about the rheological behavior of ingredients submitted to the characteristic processes in the feed industry.

In Brazil, corn and soy grains are the main ingredients in animal feed accounting for around $80 \%$ of its mass production
(SINDIRAÇÕES, 2007). According to Steffe (1996), the shear rate generated during the cereal and animal feed extrusion process varies from 0 to $10^{3} /$ second, and the temperature and pressure may range from 80 to $160{ }^{\circ} \mathrm{C}$ and from 1,500 to $6,000 \mathrm{kPa}$, respectively.

Capillary rheometry (Figure 1) is a technique that allows one to measure the rheological properties of materials subjected to a broad range of shear rate and temperature, provided one may assume that flow is laminar and constant, entry and exit effects at the capillary die are negligible, fluid is incompressible, rheological properties are not affected by time and pressure, temperature is constant, and no fluid slippage at the capillary wall occurs (DARBY, 1979).

Figure 1 illustrates the fluid flow through a capillary die of diameter $\mathrm{D}$ and length $\mathrm{L}$. The total applied pressure is $\mathrm{P}_{\mathrm{A}}$ and the capillary exit pressure is $\mathrm{P}_{\mathrm{EX}}$ (atmospheric). Extensional and shear viscosity can be estimated from the pressure drop within the cylinder and within the capillary, respectively.

Recebido para publicação em 13/2/2009

Aceito para publicação em 8/7/2009 (004056)

1 Faculdade de Engenharia Agrícola, Universidade Estadual de Campinas - UNICAMP, Cidade Universitária Zeferino Vaz, s/n, Distrito de Barão Geraldo,

CP 6011, CEP 13083-875, Campinas - SP, Brasil, E-mail: marcosfraiha@hotmail.com

${ }^{*}$ A quem a correspondência deve ser enviada 
The purpose of this work was to characterize the rheological behavior and the flow velocity profile of corn and soy mix under viscometric flow.

\section{Materials and methods}

Sample conditioning and preparation were carried out at Faculdade de Engenharia Agrícola, UNICAMP, Brazil. Corn and soy grains mixed at a proportion of 70:30 (mass) were ground in a hammermill, using a $1.5 \mathrm{~mm}$ mesh sieve. Samples were collected in order to determine the centesimal composition and particle size in triplicates. Aliquots of this material were conditioned by adding and mixing water at 15,20 , and $25 \%$ with an electric mixer, which were then placed in plastic bags and left to rest for 18 hours at $5{ }^{\circ} \mathrm{C}$ in order to bring mass moisture to equilibrium. The material was then vacuum-sealed and stored at $5{ }^{\circ} \mathrm{C}$. Aliquots were collected to determine the water content using the gravimetric method. Two-gram aliquots in duplicate were weighed on an analytical scale and dried in a forced-air oven for 24 hours at $105^{\circ} \mathrm{C}$. The measurement of the average geometric diameter of the samples followed ANSI/ASAE standard S319.3 method (AMERICAN..., 2004). True density was determined using the Archimedes method (MOHSENIN, 1986) with the use of $98^{\circ}$ ethanol instead of water to prevent particles to float. The centesimal composition of the sample was determined according to AOAC methodology (ASSOCIATION..., 1984).

The rheology tests were conducted at Centro de Tecnologia, UNICAMP, Brazil. The capillary rheometry method was used, as described by Rauwendaal (1994), using a capillary rheometer, as described by Fraiha et al. (2007), coupled to a universal testing machine (MTS, Sintech 5G). The data acquisition system, including the universal testing machine and the load cell, was calibrated for this experiment, and the expanded measurement uncertainty was $\leq 0.12 \%$, coverage factor $>2.0$ for a specific

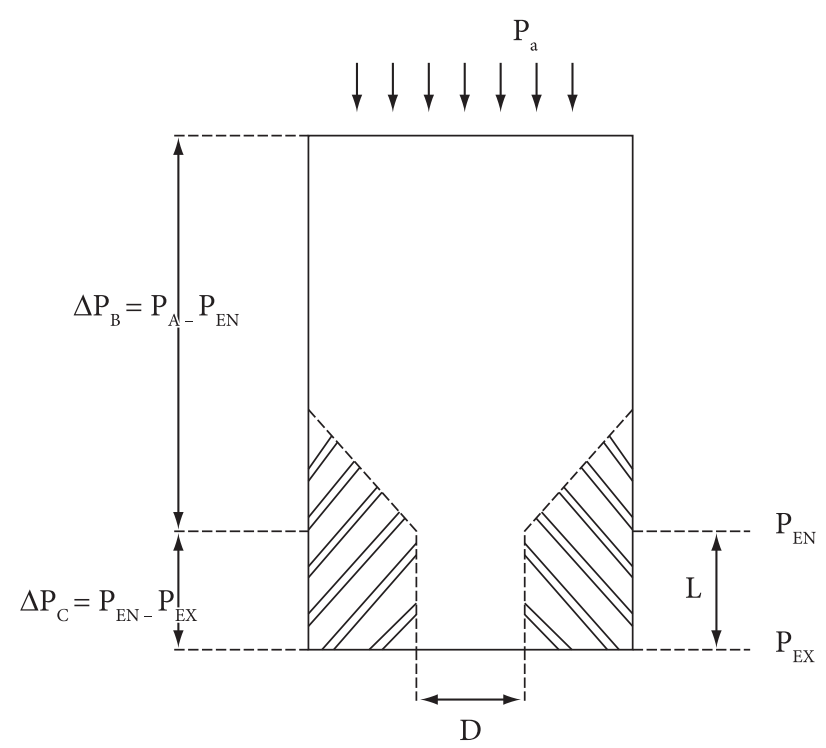

Figure 1. Illustration of fluid flow through a capillary die of diameter D and length $\mathrm{L}$. The total applied pressure is $\mathrm{P}_{\mathrm{A}}$, pressure at die exit is $\mathrm{P}_{\mathrm{EX}}$ (atmospheric), and $\mathrm{P}_{\mathrm{EN}}$ is the pressure at capillary entrance. Extensional and shear viscosity can be determined from the pressure drop within the cylinder and within the capillary, respectively. measurement range of 0 to $500 \mathrm{kgf}$ (Calibration Certificate n. 241 06CT2007).

The experiment consisted of recording the force curve during extrusion of $50 \mathrm{~g}$ of the sample through the capillary rheometer, combining dies of different dimensions and piston displacement velocities, so as to obtain pre-defined shear rates. The die dimensions used ranged from 3 to $6 \mathrm{~mm}$ inner diameter (D) and had a length to diameter ratio of 10 . Piston displacement velocities ranged from 0.4 to $4 \mathrm{~mm} /$ second.

The experimental design was completely randomized, in a $3 \times 3 \times 4$ factorial scheme with 3 levels of temperature and moisture of the mass and 4 levels of apparent shear rate. Data were collected in four replicates.

The material moisture levels were obtained via the previously described conditioning procedure and were $26.5 \pm 0.08 ; 30.4 \pm 0.31$, and $33.4 \pm 0.05 \%$ (mean \pm standard deviation). The mass temperature in the rheometer was controlled by an electrical resistance-based heating system, at 80,120 , and $160{ }^{\circ} \mathrm{C}$, allowing 3-minute come-up time for temperature equilibrium. Preliminary observations indicated that moisture loss at the highest temperature values were negligible. Apparent shear rate $\left(\dot{\gamma}_{a p}\right)$ was estimated using Equation 1 and was fixed at $30.4 ; 72.9 ; 304.3$; and 728.6/second.

$\dot{\gamma}_{a p}=\frac{32 Q_{c}}{\pi D^{3}}$

where $\mathrm{Q}_{c}$ is the volumetric flow in the capillary, determined by piston area $\left(\pi D_{p}^{2}\right)$ and displacement velocity $\left(\mathrm{v}_{\mathrm{p}}\right)$ (Equation 2$)$ :

$Q_{c}=\frac{v_{p} \pi D_{p}^{2}}{4}$

Shear tension on the capillary wall, $\tau_{p c}$, can be associated to a pressure drop along the capillary $\left(\Delta \mathrm{P}_{\mathrm{c}}\right)$ using the flowing Equation 3:

$\tau_{p c}=\frac{\Delta P_{c} D_{c}}{4 L_{c}}$

Pressure loss due to convergence of the capillary walls and loss of kinetic energy at the capillary entrance were corrected by measuring the force required for the material to flow through dies of same diameter as the test dies, but zero length $\left(\mathrm{L}_{c}=0\right)$, and then subtracted from force measured with test dies. Thus, $\Delta \mathrm{P}_{\mathrm{c}}$ can be calculated (Equation 4 ):

$\Delta P_{c}=\frac{4\left[F_{p}\left(L_{c}\right)-F_{p}\left(L_{c}=0\right)\right]}{\pi D_{p}^{2}}$

where $\mathrm{D}_{\mathrm{p}}$ is the piston diameter and $\mathrm{F}_{\mathrm{p}}$ is the force applied to the piston.

Figure 2 shows a characteristic force-strain curve obtained by displacement of the rheometer piston through time.

To calculate $\Delta \mathrm{P}_{c}$, a mean force value $(\mathrm{F})$ is obtained from the force-strain curves generated during the experiment, considering only the data from region $\beta$, as exemplified in Figure 2. Fmax represents the necessary force to initiate the material flow through the capillary die, whereas $\beta$ represents 


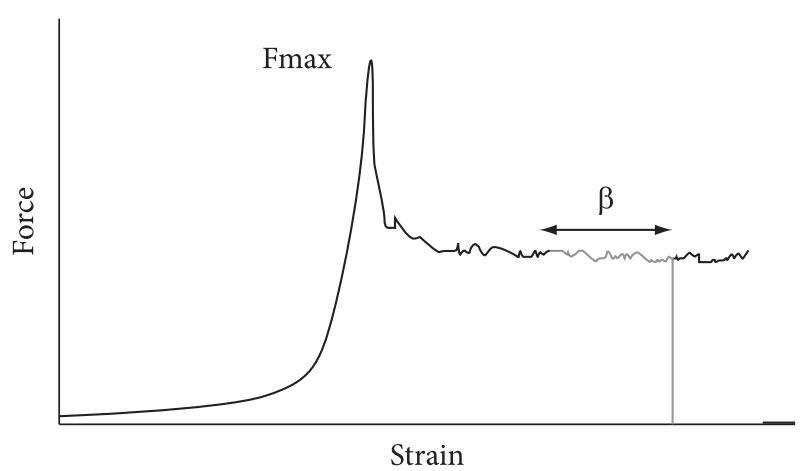

Figure 2. Force as a function of the strain imposed to the sample in the capillary; Fmax - force necessary to initiate flow; $\beta$ - portion of the curve where data is extracted for calculations.

the piston displacement required to flow a quantity of mass that is equivalent to the internal volume of the test die. The distance between Fmax and the start of $\beta$ is equal to $\beta$, meaning that a volume of mass is flowed before data collection; therefore, the data obtained for the calculations coincides with the stable force response to imposed strain. This procedure enables one to acquire average values with variation coefficients of about $5 \%$.

The estimated shear rate on the capillary wall $\left(\gamma_{p c}^{\prime}\right)$ was obtained by applying the Rabinowitsch correction to the apparent shear rate (Equation 5):

$\dot{\gamma}_{p c}=\left(\frac{3 n+1}{4 n}\right) \dot{\gamma}_{a p}$

where $n$ is the flow behavior index (Equation 6):

$n=\frac{\left(d \log \dot{\gamma}_{a p}\right)}{\left(d \log \tau_{p c}\right)}$

Apparent viscosity $(\eta)$ could then be determined (Equation 7):

$\eta=\frac{\tau_{p c}}{\dot{\gamma}_{p c}}$

The rheological behavior of the samples was represented by the Power Law (lp) and Bingham (bg) and Casson (cs) models, according to respective Equations 8, 9 and 10:

$\eta_{l p}=K_{l p}\left(\dot{\gamma}_{p c}\right)^{n-1}$

$\eta_{b g}=K_{b g}+\frac{\tau_{0}}{\dot{\gamma}_{p c}}$

$\eta_{c s} 0.5=K_{c s}+\left(\frac{\tau_{0}}{\gamma_{p c}}\right)^{0.5}$

where $K_{l p}, K_{b g}$ and $K_{c s}$ are the consistency indexes of the samples, $\tau_{0}$ is the minimum force to initiate the flow through the capillary, as determined by the extrapolation method when $\dot{\gamma}_{\mathrm{pc}}=0$ (STEFFE, 1996).

The assessment and correction of slip at the capillary wall followed the methodology described by Darby (1979) using dies of different inner diameters and same length to determine the slip coefficient $\delta$ in order to estimate slip-corrected shear rate, $\dot{\gamma}_{\text {ap,c }}($ Equation 11):

$\gamma_{a p, c}=\gamma_{a p}-\frac{8 \delta \tau_{p c}}{D}$

The mass temperature and moisture also influence the viscosity of a material. Shear rate, temperature and moisture of the mass can be combined into a single expression (HARPER; RHODES; WANNINGER, 1971) (Equation 12):

$\eta=f\left(\gamma^{\prime}, U, T\right)=K_{\gamma^{\prime}} U T\left(\gamma^{\prime}\right)^{n-1} \cdot e^{[B(U)+A(T)]}$

where the influence of shear rate is represented by the Power Law model, $\mathrm{U}$ is the material moisture (percentage), and $\mathrm{T}$ is the inverse of the testing temperature, in Kelvin scale.

The assumption of laminar flow in the capillary is a theoretical fundament in this discussion, and it is assessed by calculating the Reynolds number $\left(\mathrm{N}_{\mathrm{Re}}\right)$ (RAO; ANANTHESWARAN, 1982). A fluid governed by the Power Law (lp) presents laminar flow if (Equation 13):

$N_{\mathrm{Re}, l p}<6464 n(2+n)^{\frac{(2+n)}{(1+n)}}(1+3 n)^{-2}$

where $n$ is the flow behavior index ( $n<1$ for pseudoplastic fluids and $n=1$ for Newtonian fluids).

The Reynolds number for Power Law fluids is given as (Equation 14):

$N_{\mathrm{Re}, l p}=\left[D^{n}\left(v_{m}\right)^{2-n} \frac{\rho}{\left(8^{(n-1)} K\right)}\right]\left(\frac{4 n}{3 n+1}\right)^{n}$

where $D$ is the capillary diameter, $v m$ is the mean velocity flow through the capillary die, $\rho$ is the true density of sample, and $K$ is the consistency coefficient of the fluid $\left(\mathrm{K}=\mathrm{K}_{\mathrm{lp}}\right.$ ) (STEFFE, 1996).

The velocity profile of laminar flow in a cylinder can be estimated via Equation 15 (RAO; ANANTHESWARAN, 1982):

$\frac{v}{v_{m}}=\left(\frac{3 n+1}{n+1}\right)\left[1-\left(\frac{r}{R}\right)^{n+1 / n}\right]$

where $v$ is the flow velocity at radial position $r$ and $v m$ is the average flow velocity in the capillary, estimated from the volume of material flow due to piston displacement.

\section{Results and discussion}

The ash, ether extract, and crude protein content were $2.66 \pm 0.09 ; 7.61 \pm 0.07$; and $19.7 \pm 0.81 \%$ (mean \pm standard error), respectively (dry matter basis).

The average geometric diameter was $542.39 \pm 42.98 \mu \mathrm{m}$. The particle size may influence the sample viscosity (SERVAIS; JONES; ROBERTS, 2002). However, only very few authors provided particle size and the centesimal composition profile of the material studied; therefore a perfect comparison of results is difficult. 
Based on the original force and strain data, it was possible to estimate the apparent viscosity $(\eta)$ of the samples at different moisture, temperature, and shear rate levels. The consistency coefficient, $K$, the flow behavior index, $n$, as obtained using the Power Law model, and $K$, the minimum shear force required to initiate flow, $\tau_{0}$, as obtained through the Casson and Bingham models for the different experimental conditions, are given in Table 1.

The coefficients of determination for the Casson and Bingham models, which takes $\tau_{0}$ into account, were not better than those for the Power Law model. Alavi, Chen and Rizvi (2002) also recorded the same observation while modeling the rheological behavior of wheat starch. The existence of a true yielding behavior has been the subject of prolonged debate among rheologists since yield stress values are typically calculated by extrapolation of data (STICKEL; POWELL, 2005; TIN; GUO; UHLHERR, 2006)

Under the conditions of this experiment, the mixture of ground corn and soy grains presented a pseudoplastic behavior with a strong decline in apparent viscosity as shear rate increased, as indicated by the value of $n$ in the Power Law model (Table 1). Sandoval and Barreiro (2007) found similar behavior for corn grits when using capillary rheometry and experimental conditions very similar to the present experiment

The utilization of the Power Law model to describe the flow behavior of cereal grains has been confirmed by several authors (LI; CAMPANELLA; HARDACRE, 2004; CARVALHO; ASCHERI; MITCHELL, 2004; ALAVI; CHEN; RIZVI, 2002; SINGH; SMITH, 1999; BAGLEY; DINTZIS; CHAKRABARTI, 1998; PADMANABHAN; BHATTACHARYA, 1991; SENOUCI; SMITH, 1988).

Recently, Viamajala et al. (2009) utilized Casson and Bingham models to describe the rheological behavior of corn stover slurry at high solid concentration. The Herschel-Buckley model is also used for some authors and predicts a yield stress like the Casson and Bingham models, but its evaluation is less certain (NGUYEN; BOGER, 1992; PIMENOVA; HANLEY, 2004)

Carvalho, Ascheri and Mitchell (2004), in their work with corn grits submitted to capillary rheometry under test temperatures from 90 to $120^{\circ} \mathrm{C}$ and shear rates from 10 to
$500 /$ second, determined values of $n$ ranging from 0.16 to 0.52 , and of Klp from 2.6 to $97.8 \mathrm{kPa} . \mathrm{s}^{\mathrm{n}}$. Singh and Smith (1999) obtained values of $n$ and $K l p$ ranging from 0.17 to 0.51 and 3 to $93 \mathrm{kPa} . \mathrm{s}^{\mathrm{n}}$, respectively, for wheat flour with a water content from 21 to $28 \%$ and at temperatures of 100 to $125^{\circ} \mathrm{C}$.

The negative $n$ index obtained for the samples with $33.4 \%$ water content at $120^{\circ} \mathrm{C}$ (Table 1$)$ is difficult to explain although the negative flow behavior indexes had already been reported in the past. Padmanabhan and Bhattacharya (1991), studying the behavior of ground corn with moisture levels ranging from 25 to $45 \%$ at temperatures ranging from 150 to $180^{\circ} \mathrm{C}$, obtained $-0.193 \leq \mathrm{n} \leq 0.811$ and $1.42 \times 10^{2} \leq K l p \leq 7.52 \times 10^{5}$. These authors varied the apparent shear rate from 163 to 652 /second, and thereby obtained an apparent viscosity ranging from 98 to 1276 Pa.s, values which are close to the ones obtained in the present study. Their hypotheses to explain the negative values of $n$ include molecular degradation of sample, viscous dissipation, fluid slip along the capillary wall, and the influence of $\tau_{0}$ although the contribution of each of these factors was not clear. In the present experiment, sample slip may be involved, which could explain the negative $n$.

Few authors assessed the presence of slip on the capillary wall. In the present experiment, the corrections resulted in inconsistent data attributing negative values to $\dot{\gamma}_{\text {ap,c }}$. Other authors have obtained similar results and could not proceed with the correction (MACKEY et al., 1989; SINGH; SMITH, 1999).

Based on the experimental data, excluding those with a negative $n$, the constants $\mathrm{K}_{\gamma^{\prime} \mathrm{UT}}, \bar{n}, \mathrm{~B}$, and $\mathrm{A}$ (Equation 12) were determined by multiple regression $\left(\mathrm{p}<0.001, \mathrm{R}^{2}=0.93\right)$, resulting in the expression (Equation 16):

$$
\eta=18769.7(\dot{\gamma})^{-0.86} e^{(-9.34 U+935 T)}
$$

A comparison of the observed data and the estimated data from the general model, including the effects of shear rate, based on the Power Law model, water content, and temperature (Equation 16), is shown in Figure 3.

Under the conditions of this experiment, with $n=0.14$, the flow is considered laminar if $\mathrm{N}_{\mathrm{Re}, \mathrm{lp}}<1876.2$.

In this experiment, the capillary flow could be estimated by considering the maximum piston displacement velocity as

Table 1. Consistency coefficients (K), flow behavior indexes (n) as determined by the Power Law model, and (K) and minimum shear forces required to initiate flow $\left(\tau_{0}\right)$, as determined by the Casson and Bingham models for the different experimental conditions.

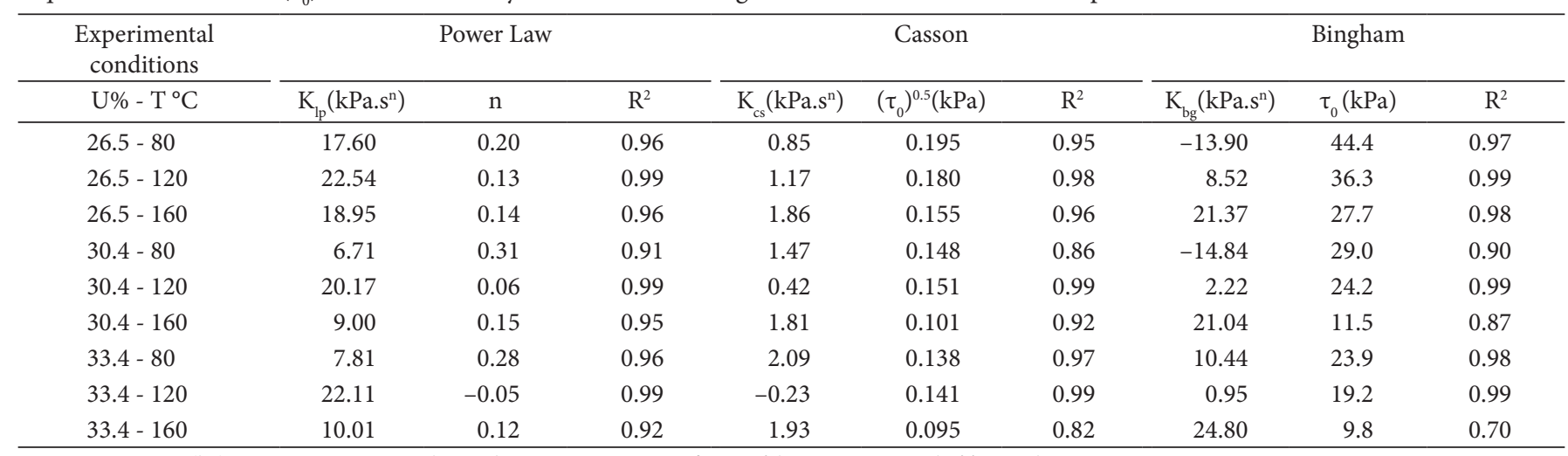

$\mathrm{U}$ - mass moisture (bu); T - mass temperature during the experiment, $\mathrm{R}^{2}$ - coefficient of determination, total of four replicates. 
$4 \mathrm{~mm} / \mathrm{second}$, and the inner diameter of the rheometer cylinder as $24.3 \mathrm{~mm}$. Hence, the average velocity flow $(\mathrm{vm})$ through the capillary with $3 \mathrm{~mm}$ diameter was estimated as $262.4 \mathrm{~mm} / \mathrm{second}$. The true density $(\rho)$ was previously determined as $1300 \mathrm{~kg} \cdot \mathrm{m}^{-3}$. Based on these data, the Reynolds Number was estimated as 0.37 , indicating that flow is laminar, thereby fulfilling a basic theoretical assumption made in this experiment.

The flow velocity profile of an incompressible fluid through a cylindrical canal may be estimated. Under steady state flow, a ring-shaped portion of the fluid next to the canal wall presents a velocity gradient, where parts of the fluid move in relation to their adjacent areas (Figure 4). In the central region of the canal, delimited by $r$, the fluid flows freely without forming a velocity gradient.

Figure 5 shows the velocity profile of a fluid submitted to viscometric flow as a function of radial position in relation to the capillary wall.

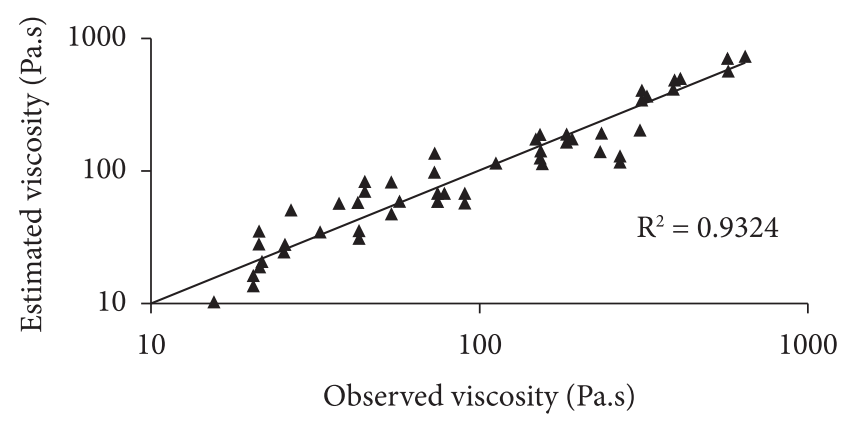

Figure 3. Modeled apparent viscosity versus observed viscosity.

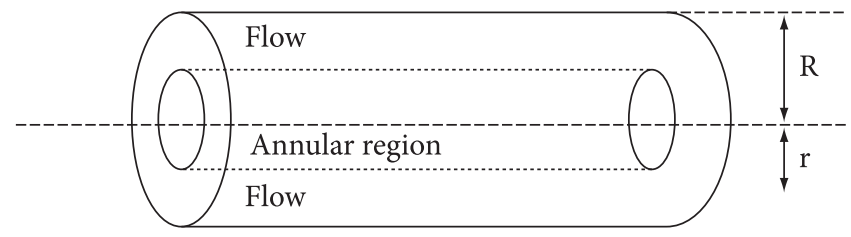

Figure 4. Poiseuille flow, $\mathrm{R}$ - radius; $\mathrm{r}$ - distance from the annular center to a given point. In the annular region, theoretically, there is no gradient of velocity between a given point and its adjacencies. In the flow region, such gradient of velocity is expected to occur.

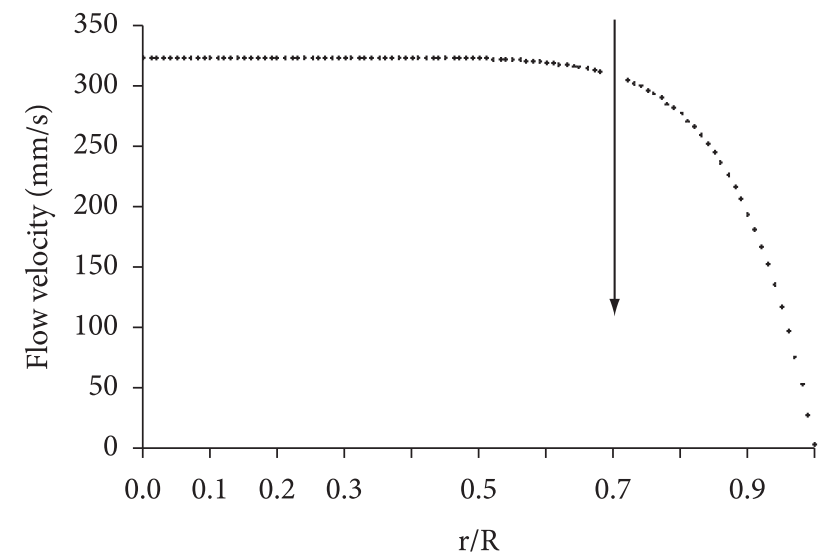

Figure 5. Flow velocity profile as a function of $\mathrm{r} / \mathrm{R}$ ratio; arrow indicates the end of the constant flow velocity.
By analogy, the zero value of $\mathrm{r} / \mathrm{R}$ in Figure 5 represents the center, and the 1 value represents the capillary wall. The maximum flow velocity was estimated as $323 \mathrm{~mm} /$ second at the capillary center. It can be observed that most of the mass is not subjected to a velocity gradient while flowing. The marked region under the curve in Figure 5, between 0.7 and $1 \mathrm{r} / \mathrm{R}$, represents the portion of mass under shear while flowing, and its volume is estimated as $50 \%$ of the mass, approximately. It is worth to note that such volume depends on the flow behavior index $n$ only, as implied by Equation 9, regardless of the average flow velocity.

\section{Conclusions}

Ground corn and soy grain exhibit a pseudoplastic behavior under viscometric flow, represented by the Power Law model.

The velocity profile of such mixture under viscometric flow indicates that a large portion is not submitted to a velocity gradient.

\section{Acknowledgements}

The authors are grateful for the financial support provided by the Fundação de Amparo à Pesquisa do Estado de São Paulo FAPESP (The State of São Paulo Research Foundation). We thank Prof. Dr. Claudio Sverzut who kindly permitted us to use the universal testing machine at Centro de Tecnologia, Unicamp.

\section{References}

ALAVI, S. H.; CHEN, K. H.; RIZVI, S. S. H. Rheological characteristics of intermediate moisture blends of pregelatinized and raw wheat starch. Journal of Agricultural Food Chemistry, v. 50, p. 6740-45, 2002.

AMERICAN SOCIETY OF. Method of determining and expressing fineness of feed materials by sieving. ANSI/ASAE S319.3. In: ASAE. Agricultural engineers yearbook of standard. 51th ed. St. Joseph: ASAE, 2004. p. 578-81.

ASSOCIATION OF OFFICIAL ANALYTICAL CHEMISTS - AOAC. Official methods of analysis. 14th ed. Washington, DC: AOAC, 1984. $1141 \mathrm{p}$.

BAGLEY, E. B.; DINTZIS, F. R.; CHAKRABARTI, S. Experimental and conceptual problems in the rheological characterization of wheat flour doughs. Rheologica Acta, v. 37, p. 556-65, 1998.

PADMANABHAN, M.; BHATTACHARYA, M. Flow behavior and exit pressures of corn meal under high-shear-high temperature extrusion conditions using a slit die. Journal of Rheology, v. 35, n. 3, p. 315-42, 1991.

CARVALHO, C. W. P.; ASCHERI, J. L. R.; MITCHELL, J. R. Capillary rheometry of maize and wheat: effect of sugar and temperature. Alimentaria, p. 109-18, 2004.

DARBY, R. Viscoelastic fluids, an introduction to their properties and behavior. New York: Marcel Dekker, 1979. 638 p.

EERIKAINEN, T.; LINKO, P. Extrusion cooking modeling, control and optimization In: MERCIER, C. et al. Extrusion cooking, american association of cereal chemists. Minnesota, 1998. p. 157-204.

FRAIHA, M. et al. Projeto e construção de reômetro capilar. In: CONGRESSO BRASILEIRO DE ENGENHARIA AGRÍCOLA, 36., 2007, Bonito. Anais... Sociedade Brasileira de Engenharia Agrícola, 2007. 
HARPER, J. M.; RHODES, T. P.; WANNINGER, L. A. Viscosity model for cooked cereal doughs. AIChE Symposium Series, v. 67, p. 40-3, 1971.

LI, P. X.; CAMPANELLA, O. H.; HARDACRE, A. K. Using a in-line slit-die viscometer to study the effects of extrusion parameters on corn melt rheology. Cereal Chemistry, v. 81, n. 1, p. 70-6, 2004.

MACKEY, K. et al. Rheological modeling of potato flour during extrusion cooking. Journal of Food Processing Engineering, v. 12, p. 1-11, 1989.

MOHSENIN, N. N. Physical properties of plant and animal materials. $2^{\text {nd }}$ ed. New York: Gordon and Breach Science, 1986. 734 p.

NGUYEN, Q. D.; BOGER, D. V. Measuring the flow properties of yield stress fluids. Annual Review of Fluid Mechanics, v. 24, p. 47-85, 1992.

PIMENOVA, N. V.; HANLEY, T. R. Effect of corn stover concentration on rheological characteristics. Applied Biochemistry and Biotechnology, v. 113, p. 347-60, 2004.

RAO, M. A.; ANANTHESWARAN, R. C. Rheology of fluids in food processing. Food Technology, 1982.

RAUWENDAAL, C. Polymer extrusion. $3^{\text {rd }}$ ed. New York: Hanser Gardner Publishers, 1994. 568 p.

REMSEN, C. H.; CLARK, J. P. A viscosity model for a cooking dough. Journal of Food Processing Engineering, v. 2, p. 39-64, 1978.
SANDOVAL, A. J.; BARREIRO, J. A. Off-line capillary rheometry of corn starch: Effects of temperature, moisture content and shear rate. Food Science and Technology, v. 40, p. 43-48, 2007.

SENOUCI, A.; SMITH, A. C. An experimental study of food melt rheology: I. Shear viscosity using a slit die viscometer and a capillary rheometer. Rheologica Acta, v. 27, p. 546-54, 1998.

SERVAIS, C.; JONES, R.; ROBERTS, I. The influence of particle size distribution on the processing of food. Journal of Food Engineering, v. 51, p. 201-8, 2002.

SINDIRAÇÕES. Perfil 2007. Disponível em: <http://www.sindiracoes. org.br/imagens/UserFiles/Image/Sindiraes/Perfil/Perfil_2006_2E_ Produc_Bras_15.gif $>$. Acesso em: dec. 2007.

SINGH, N.; SMITH, A. C. Rheological behavior of different cereals using capillary rheometry. Journal of Food Engineering, v. 39, p. 203-09, 1999.

STEFFE, J. F. Rheological methods in food process engineering. $2^{\text {nd }}$ ed. Freeman Press: East Lansing, 1996. 417 p.

STICKEL, J. J.; POWELL, R. L. Fluid mechanics and rheology of dense suspensions. Annual Reviews in Fluid Mechanics, v. 37, p. $129-49,2005$

TIN, C.; GUO, J.; UHLHERR, P. H. T. Yielding behaviour of viscoplastic materials. Journal of Industrial and Engineering Chemistry, v. 12, p. 653-62, 2006.

VIAMAJALA, S. et al. Rheology of corn stover slurries at high solids concentrations - Effects of saccharification and particle size. Bioresource Technology, v. 100, p. 925-34, 2009. 